\title{
A Feasibility Study on Production of Concrete Blocks Using Treated Municipal Solid Waste Leachate
}

Negar Esmaeili

Kharazmi University

Nima Heidarzadeh ( $\nabla$ n.heidarzadeh@gmail.com )

Kharazmi University https://orcid.org/0000-0002-3130-407X

\section{Research Article}

Keywords: Treated leachate, Concrete, Unconfined Compressive Strength, SEM, TCLP

Posted Date: May 12th, 2021

DOl: https://doi.org/10.21203/rs.3.rs-466643/v1

License: (c) (1) This work is licensed under a Creative Commons Attribution 4.0 International License.

Read Full License 


\section{Abstract}

Population growth and development have increased the need for drinking water all over the world. Hence, it is required to find an alternative to water in different industries. Concrete represents a remarkable waterconsuming industry. The present study investigates whether the treated leachate of municipal landfills can be employed as a substitute for water in the concrete mixing scheme. For this purpose, concrete samples fabricated at different concentrations of treated leachates were compared to the control sample containing distilled water in terms of unconfined compressive strength (UCS) at the ages of 7 and 28 days. The experimental results revealed treated leachate accelerated the cement setting time by nearly 15 min and increased concrete slumping by $16 \%$. The complete replacement of distilled water with treated leachate decreased UCS by 25\% (from 50 to $38 \mathrm{MPa}$ ). The scanning electron microscope (SEM) and ultrasonic results showed that a rise in the treated leachate content of concrete increased porosity. Increased porosity would reduce UCS. The presence of heavy metals and leaching from the cement matrix are important characteristics of leachates. The toxicity characteristic leaching procedure (TCLP) revealed that the leaching of heavy metals in all the samples was in the acceptable range.

\section{Introduction}

The landfilling of municipal solid waste (MSW) has been greatly interesting in light of its easy process and affordability. However, as it contains heavy metals and dangerous organic and inorganic compounds, the leachates of landfills are considered as a serious threat to the environment (Xu et al. 2018). The per capita waste production rate of Iran is nearly $700 \mathrm{~g} /$ day. It equals 52,000 tons of domestic waste every day. Such waste has a high content of biodegradable organic matter (60-70\%), with remarkable leachate quantities. This results in huge leachate lakes in landfills (Mokhtarani et al. 2014). Leachates arise from three main sources: 1) water content in the organic waste changing into leachate over time, 2) biochemistry reactions in landfills, and 3) rainfall and runoff events (Renou et al. 2008). The leachate of a landfill is increased by factors such as rainfall and surface runoff as they can penetrate and contaminate groundwater resources (Sruthi et al. 2018). Concrete is the second most-consumed material in the world (Luhar et al. 2019). It consists $7-15 \%$ of cement, nearly $14-21 \%$ of water, and $60-75 \%$ of aggregates (Shekarchi et al. 2012). Nearly 3.8 billion cubic meters of concrete are constructed annually all over the world. To fabricate one cubic meter of concrete, 150 liters of water is required (Meena and Luhar 2018). Concrete fabrication requires an average freshwater quantity of 570 billion liters every year. Increased water demand due to population growth and industrialization has led to increased water consumption. Therefore, more wastewater is produced, the disposal of which could endanger both local residents and the environment. Thus, the use of raw and treated wastewater for concrete fabrication could reduce the demand for freshwater and mitigate threats to human health, significantly contributing to environmental protection (Noruzman et al. 2012). The water used in concrete should be free of oils, acids, organic materials, and alkalinity (Reddy-Babu et al. 2018). In most parts of the world, freshwater is used for concrete fabrication. As global warming and drought are increasing in many countries, it is becoming an international challenge to identify a suitable substitute for freshwater in construction. 
Therefore, many studies have sought to find a solution to employ raw or treated municipal and industrial wastewater. Cebci and Saatci (1989) used treated wastewater in concrete production, reporting that treated wastewater had no significant effect on compressive strength and the setting time compared to the distilled water-fabricated samples. El-Nayway and Ahmad (1991) diluted treated municipal wastewater by water and used different diluents in concrete production. For a mixture of $20 \%$ treated wastewater and $80 \%$ freshwater, $90 \%$ of the compressive strength of the control sample was retained. Ooi et al. (2001) studied the possibility of using treated wastewater in concrete. Treated wastewater was found to increase the compressive strength at the ages of 7,28 , and 90 days as compared to freshwater. Su et al. (2002) investigated the impacts of underground water and wastewater produced from washing in a concrete factory, comparing the results to freshwater in terms of compressive strength and the setting time. The use of underground water had no effect on the cement setting time, while the use of washing wastewater from mixer washout concrete decreased the setting time as compared to the control sample and increased the compressive strength as compared to the sample fabricated with underground water. Terro and Al-Ghusian (2003) employed primary, secondary, and advanced treated wastewater in concrete production with a curing age of 21 days for up to 1.5 years. They found that the quality of wastewater in concrete affected compressive strength for up to 1.5 years of processing and decreased the strength of the samples. However, the compressive strength results and sample slumps of advanced treated wastewater were much closer to those of the distilled water-fabricated samples and were concluded to be a good alternative. Saricimen et al. (2014) used treated wastewater as a substitute for drinking water in concrete. They reported that the use of treated wastewater reduced the setting time and increased the 90-day compressive strength. Ismail and Al-Hashemi (2011) investigated the usability of industrial polyvinyl acetate resin wastewater as a substitute for freshwater. It resulted in a substantial decrease in the slump rate of concrete, with no significant change in compressive and bending strengths. Silva and Naik (2010) examined the impacts of using municipal treated wastewater on concrete production. They concluded that municipal treated wastewater had no significant effect on compressive strength. Al-Jabri et al. (2011) analyzed the effects of using wastewater from a carwash station on the mechanical properties of high-strength concrete. They found that wastewater had a small effect on the 28-day compressive strength of concrete. Norazman et al. (2012) examined the leaches of industrial refined wastewater from heavy industries and an oil palm factory on concrete. They reported that domestic wastewater and oil palm factory wastewater reduced the setting time, while refined wastewater from heavy industries increased the setting time. The compressive strength of the treated wastewaterfabricated concrete samples was higher than that of the control sample. The other wastewater types had the opposite effect. Shekarchi et al. (2012) concluded that the use of domestic treated wastewater had no significant effect on the slump of concrete samples. The impact of treated wastewater on concrete was much more significant at the ages of 3,7 , and 28 days than at longer curing ages. Also, the advanced treated wastewater-fabricated samples had higher compressive strength than the primary and secondary wastewater and freshwater-fabricated samples. Mahasneh (2014) compared the strength of treated and raw wastewater-containing concrete samples to that of freshwater-fabricated samples. The chemical properties of treated wastewater were similar to those of freshwater, while the chemical properties of the raw wastewater differed from those of freshwater. As a result, the compressive strength of the samples 
fabricated with raw wastewater experienced a larger reduction than the treated wastewater-fabricated samples. Nikhil et al. (2014) used groundwater and wastewater to produce concrete and reported that the use of drinking water to replace groundwater led to $30 \%$ and $13 \%$ reduction in the 28 -day compressive strength compared to the control sample. Mostafa and Peters (2017) investigated the effects of wastewater from the paint industries on the mechanical properties of cement tiles and bricks. The use of wastewater had no negative impact on the mechanical properties of tiles and bricks. They also used the TCLP method to evaluate heavy metal leachate from cement tiles and bricks. The extracted heavy metals were lower than the EPA allowable quantities in the TCLP method, and no environmental impacts due to heavy metal leachate were demonstrated. Zhan and Poon (2015) utilized treated wastewater sludge from textile industries in concrete production. The presence of organic materials delayed cement setting, and compressive strength decreased as sludge increased. Through the TCLP method, it was found that wastewater heavy metals were stabilized and solidified by the use of the wastewater in the concrete, and they would impose environmental impacts. Asadollahfardi et al. (2016) studied the use of nonchlorinated treated domestic wastewater for the production and curing of concrete. They reported that wastewater made no significant difference in the slump compared to drinking water. The use of wastewater increased the setting time, and it had a smaller negative impact at longer curing ages. The compressive strength of the wastewater fabricated-samples made showed no significant difference from that of the control sample at high curing ages. The SEM images revealed that the porosity of the wastewater-fabricated samples was higher than that of drinking water-fabricated samples. Ghrair et al. (2018) explored the effects of grey water on the physical and mechanical properties of mortars and concrete mix in Jordan. The use of gray water reduced the slump as compared to the distilled waterfabricated sample. Also, the 7-day compressive strength of these samples was lower than that of the distilled water-fabricated samples. However, the 28- and 120-day compressive strength showed no significant difference. Manunatha and Dhunra (2017) fabricated concrete samples using treated wastewater. The compressive strength of the samples exhibited a $12 \%$ increase at the age of 7 days as compared to the control sample. At the curing ages of 14 and 28 days, the compressive strength of the drinking water-fabricated samples increased by $2 \%$. The SEM images of treated wastewater-fabricated samples showed no difference from the drinking water-fabricated samples. Meena and Luhar (2019) used advanced and secondary treated wastewater and freshwater to produce concrete. The use of secondary wastewater in place of drinking water reduced the slump by $50 \%$ as compared to the control sample. The complete replacement of freshwater with advanced treated wastewater and sample curing within freshwater reduced the compressive strength of the samples at different curing ages by $85-94 \%$ as compared to the control sample. Saxena and Tembhurkar (2019) exploited freshwater and natural basalt as coarse grains in the mixing scheme and replaced freshwater with treated wastewater. This reduced the slump of the samples by $10 \%$ as compared to the freshwater-fabricated samples. Also, treated wastewater diminished compressive strength by $3-4 \%$ at the ages of $7,28,56$, and 90 days. The ultrasonic pulse velocity test showed that the use of treated wastewater reduced the pulse velocity by 4$5 \%$ as compared to the control sample. The SEM images suggested that the treated wastewater induced pores within the concrete. This can be attributed to the presence of organic materials and solids in wastewater. 
The present study uses MSW treated leachate to replace distilled water in concrete production in order to analyze the effects of the leachate on the mechanical properties of concrete and realize whether leachate could be employed in concrete production to save water.

\section{Materials And Methods}

To fabricate concrete samples, the present study used treated leachate from the Kahrizak, the central landfill in Tehran Province, Iran. Biological leachate treatment methods are common, economical, and highly effective methods for eliminating degradable organic materials (Sruthi et al. 2018). At the Kahrizak Treatment Plant, young leachates enter the anaerobic lagoon, where chemicals such as sodium bicarbonates, urea, and hydrogen disodium phosphate are injected into the raw leachate. After the completion of biological filtration, lime is injected as the $\mathrm{pH}$ stabilizer into the leachate. Then, chloroform is injected into the leachate as a coagulant and segregates the leachate clots. Chloroform enters the sedimentation pond. In the sedimentation stage, the leachate is separated from the sludge and directed to the aerobic tank to be refined over the detention time. The air within the aeration tank is injected through diffusers. After aeration, the leachate enters the membrane bioreactor (MBR) filtration system to be finalized through the available membranes. Eventually, chlorination is carried out to disinfect the treated leachate and maintain it in predetermined tanks.

Table 1 Properties of Type 2 Portland cement used in the samples of the current study

\begin{tabular}{cc}
\hline $\begin{array}{l}\text { Chemical } \\
\text { Characteristic }\end{array}$ & $\begin{array}{l}\text { Type } 2 \text { Portland } \\
\text { cement }\end{array}$ \\
\hline $\mathrm{SiO}_{2}$ & 20.79 \\
$\mathbf{A l}_{2} \mathbf{O}_{3}$ & 4.76 \\
$\mathbf{F e}_{2} \mathbf{O}_{3}$ & 3.86 \\
$\mathbf{C a O}$ & 62.28 \\
$\mathbf{M g O}$ & 3.22 \\
$\mathbf{S O} \mathbf{O}_{3}$ & 1.89 \\
$\mathbf{K}_{2} \mathbf{O}$ & 0.68 \\
Heat loss & 1.88 \\
Remained Insoluble & 0.51 \\
Free lime & 0.82 \\
$\mathbf{C}_{3} \mathbf{S}$ & 52.67 \\
$\mathbf{C}_{2} \mathbf{S}$ & 19.89 \\
$\mathbf{C}_{3} \mathbf{A}$ & 6.09 \\
\hline
\end{tabular}


In the present research, seventy-two $150 \times 150 \times 150$-mm cubic samples were fabricated by a mixing scheme design at a water-cement ratio of 0.5 and using $400 \mathrm{~kg}$ of type 2 Portland cement per cubic meter, as reported in Table 1. To demonstrate the impacts of the treated leachate on concrete, different concentrations of treated leachate were used to replace distilled water, as shown in Table 2, For a better comparison of the treated leachate-fabricated samples, a control sample was built using distilled water.

Table 2 Naming of the samples made with different percentage of treated leachate

\begin{tabular}{lcc}
\hline $\begin{array}{l}\text { Sample } \\
\text { name }\end{array}$ & $\begin{array}{l}\text { Distilled water } \\
(\%)\end{array}$ & $\begin{array}{l}\text { Treated Leachate } \\
(\%)\end{array}$ \\
\hline $\mathbf{W}_{\mathbf{1 0 0}} \mathbf{L}_{\mathbf{0}}$ & 100 & 0 \\
$\mathbf{W}_{\mathbf{9 5}} \mathbf{L}_{\mathbf{5}}$ & 95 & 5 \\
$\mathbf{W}_{\mathbf{9 0}} \mathbf{L}_{\mathbf{1 0}}$ & 90 & 10 \\
$\mathbf{W}_{\mathbf{8 5}} \mathbf{L}_{\mathbf{1 5}}$ & 85 & 15 \\
$\mathbf{W}_{\mathbf{8 0}} \mathbf{L}_{\mathbf{2 0}}$ & 80 & 20 \\
$\mathbf{W}_{\mathbf{7 0}} \mathbf{L}_{\mathbf{3 0}}$ & 70 & 30 \\
$\mathbf{W}_{\mathbf{6 0}} \mathbf{L}_{\mathbf{4 0}}$ & 60 & 40 \\
$\mathbf{W}_{\mathbf{5 0}} \mathbf{L}_{\mathbf{5 0}}$ & 50 & 50 \\
$\mathbf{W}_{\mathbf{3 0}} \mathbf{L}_{\mathbf{7 0}}$ & 30 & 70 \\
$\mathbf{W}_{\mathbf{2 0}} \mathbf{L}_{\mathbf{8 0}}$ & 20 & 80 \\
$\mathbf{W}_{\mathbf{1 0}} \mathbf{L}_{\mathbf{9 0}}$ & 10 & 90 \\
$\mathbf{W}_{\mathbf{0}} \mathbf{L}_{\mathbf{1 0 0}}$ & 0 & 100 \\
\hline
\end{tabular}

It is worth mentioning that other conditions and materials were considered to be the same for all the samples. The cubic samples fabricated according to the ASTM-C192 Standard (2004) were poured into three equal layers; each layer was compressed before pouring into the subsequent layer. The molded samples were kept at ambient temperature for 24 hours and at a humidity of $65 \%$ using a wet sack. Then, the samples were kept separately for 7 and 28 days of curing. Table 1 describes type 2 Portland cement (ASTM-C150 2004). The characteristics of type 2 Portland cement include medium resistance to sulfate attacks and moderate hydration heat. This type of cement is widely used in construction in Iran. Table 3 reports the properties of the treated leachate used to replace distilled water at various concentrations. 
Table 3 Selected physical and chemical properties of the treated leachate of the Tehran municipal solid wastes landfill (Kahrizak)

\begin{tabular}{ccc}
\hline Specification & Unit & Value \\
\hline $\mathrm{pH}$ & -- & 7.3 \\
$\mathrm{BOD}$ & $\mathrm{ppm}$ & 134 \\
$\mathrm{COD}$ & $\mathrm{ppm}$ & 256 \\
$\mathrm{TOC}$ & $\mathrm{ppm}$ & 64 \\
$\mathrm{TSS}$ & $\mathrm{ppm}$ & 627 \\
$\mathrm{TDS}$ & $\mathrm{ppm}$ & 13200 \\
$\mathrm{Cl}$ & $\mathrm{ppm}$ & 14060 \\
$\mathrm{~S}$ & $\mathrm{ppm}$ & 7672 \\
$\mathrm{Ag}$ & $\mu \mathrm{g} / \mathrm{l}$ & 3.2 \\
$\mathrm{As}$ & $\mathrm{mg} / \mathrm{l}$ & 0.75 \\
$\mathrm{Ba}$ & $\mathrm{mg} / \mathrm{l}$ & 152 \\
$\mathrm{Cd}$ & $\mathrm{mg} / \mathrm{l}$ & 0.75 \\
$\mathrm{Cr}$ & $\mu \mathrm{g} / \mathrm{l}$ & 112 \\
$\mathrm{Cu}$ & $\mu \mathrm{g} / \mathrm{l}$ & 79.1 \\
$\mathrm{~Pb}$ & $\mu \mathrm{g} / \mathrm{l}$ & 43 \\
$\mathrm{Ni}$ & $\mu \mathrm{g} / \mathrm{l}$ & 211 \\
\hline
\end{tabular}

Aggregates were obtained from a sand mining site in Alborz Province, Iran. According to the ASTM-C136 Standard 2004, a gravel diameter of 4.75-19.00 mm was used to fabricate coarse-grained concrete. Sand with a diameter of 0-4.75 mm and a fineness modulus of 2.48 was employed based on the ASTM C-33 Standard 2004. The slump test was performed based on the ASTM-C143 Standard 2004.

To investigate the effects of the treated leachate on the setting of cement, the initial cement setting test was performed by the ASTM-C191 Standard 2004. Three UCS measurements were measured based on the BSI 1881-108 Standard at the ages of 7 and 28 days. Also, the ultrasonic test was performed based on the ASTM-C597 Standard 2016. The ultrasonic energy reduces through air-induced pores. To prevent ultrasonic energy reduction, a gel-like material should be used between the device probes and concrete surface. In addition, this test works best on a smooth surface without concrete pores (Kaur et al. 2019). In the ultrasonic test, a high ultrasonic wave velocity represents high concrete quality, while a low ultrasonic wave velocity implies low concrete quality. The ultrasonic pulse velocity results were compared to those of the SEM test performed using a TESCAN VEGA3 electron microscope at magnifications of 200 and 10 $\mu \mathrm{m}$ according to the ASTM-C1723-10 Standard 2010.

Leachates contain heavy metals and may lead to the leaching of such substances. The introduction of contaminants and toxins into homes is a concern regarding the use of waste and wastewater in construction (Cusidó and Cremades 2012). There are many leachate evaluation methods, such as TCLP and ASTM-D3987, for the leachate of toxic materials. These two methods are the most common techniques (Ma and Garbers-Craig 2009). Karamalidis and Voudrias (2007) employed cement to stabilize and solidify sludge from an oil refinery. They used the TCLP test to investigate the leaching behavior of 
alkanes and PAHs; however, citric acid was used in place of distilled water (according to the TCLP method) since sludge from refineries is admitted in hazardous waste landfill centers that differ from typical landfills. Acid was used as the extraction liquid in the TCLP method to represent landfill conditions. Distilled water was used to investigate heavy metal leakage since the present study fabricated samples using treated leachate, and the fabricated concrete would be exposed to water rather than acidic media and disposed of urban landfill centers. The ASTM-D3987 Standard 1995 uses distilled water as the extraction liquid in leakage testing. A solid sample-extracted solution ratio of 1:20 was applied. The heavy metal leakage evaluation of the concrete sample containing $100 \%$ treated leachate was carried out. $20 \mathrm{~g}$ of the fabricated concrete were subjected to a 10-mm sieve and then blended with $100 \mathrm{ml}$ of distilled water at a speed of $30 \pm 2 \mathrm{rpm}$ for $18 \pm 2$ hours to investigate the leakage of heavy metal (Environmental Protection Agency, 2004). An inductive coupled plasma mass spectrometer (ICP-MS) was employed to derive heavy metals from the extraction liquid. The extracted fluid contained sodium hydroxide and glacial acetic acid. This was the difference from the ASTM-D3987 method. Chang et al. (2001) and Dungan and Dees (2009) compared different leaching methods, including TCLP and ASTMD3987, concluding that the concentrations of some heavy metals in the TCLP leaching test of TCLP were higher than those in the ASTM-D3987 test due to the use of acids rather than distilled water in TCLP and the effect of TCLP on the heavy metal concentration. Furthermore, the x-ray fluorescence (XRF) test was carried out to evaluate the chemical composition of the treated leachate-fabricated concrete and compare it to the distilled water-fabricated sample according to the ASTM-E1621-13 Standard.

\section{Results And Discussion}

Fig.1 compares the initial cement setting time between distilled water- and treated leachate-fabricated samples. As can be seen, treated leachate shortened the setting time by nearly $15 \mathrm{~min}$ - the initial leachate time was found to be $48 \mathrm{~min}$. According to ASTM-C191 2004, if the setting time changes from 1 hour earlier to 1.5 hours later, the corresponding mixing water is acceptable. Since the difference in the setting time between the treated leachate and distilled water is within the range, the mixing water is acceptable. The cement setting time is dependent on water quality. These results are in agreement with Su et al. (2002), Saricimen et al. (2014), and Noruzman et al. (2012). The rate of the cement hydration reaction in the mixing process is strongly dependent on the ions and the physical and chemical properties of water. This would change the setting time as compared to the solid sample (Saricimen et al. 2014).

Slump is an important characteristic of concrete as it represents the usability of concrete and serves as a measure to estimate concrete strength. A block of concrete with a proper slump is easily molded and compacted. The slump test helps evaluate the quality of concrete; excessively small or large slumps would be negative characteristics of concrete. The replacement of distilled water with treated leachate did not remarkably affect the slumps of the samples. The complete replacement of distilled water with treated leachate increased the sample slump by $10 \mathrm{~mm}$.

Earlier works reported that the use of raw and treated wastewater in concrete decreased the slumps probably due to the physical and chemical properties of wastewater (Ismail and Al-Hashemi 2011; Meena 
and Luhar 2019). However, Asadollahfardi et al. (2016) found that the use of effluent before chlorination did not affect the slump and induced a difference of nearly $5 \mathrm{~mm}$ from the control sample. BS 8500-1 2006 divides slumps into five groups based on their efficiency. According to the results, the slumps of the samples fall into group S2 and suit reinforced concrete beams and columns.

The ultrasonic pulse velocity test is a non-destructive test to measure homogeneity and strength in concrete. It allows for qualitatively evaluating concrete strength. A higher ultrasonic pulse velocity represents a larger elasticity modulus, density, and strength. Fig. 3 plots the ultrasonic pulse velocity versus the treated leachate concentration at the age of 28 days. The use of up to $10 \%$ treated leachate in concrete did not affect the ultrasonic pulse velocity; thus, it can be said that $10 \%$ treated leachate would not affect compressive strength; however, a further increase in the treated leachate concentration reduced the ultrasonic pulse velocity at a higher rate. The complete replacement of distilled water with treated leachate resulted in a $6.5 \%$ decrease in the ultrasonic pulse velocity as compared to the control sample (i.e.,100\% distilled water). Saxena and Tembhurkar (2019) observed that the replacement of distilled water with treated wastewater resulted in a decrease in the ultrasonic pulse velocity.

The mechanical behavior and compressive strength of concrete are dependent on its structure, cement paste, aggregates, and component ratio. According to Fig.2, as with treated wastewater, the treated leachate reduced compressive strength. Noruzman et al. (2012), Terro and Al-Ghusian (2003), Saricimen et al. (2014), Meena and Luhar (2019), Saxena and Tembhurkar (2019) reported reduced compressive strength as compared to the control sample, depending on the quality of wastewater. According to Fig. 2 , a rise in the treated leachate decreased compressive strength. This is supportive of reduced ultrasonic pulse velocity due to increased treated leachate. The use of up to $10 \%$ treated leachate had no significant effect on compressive strength at the ages of 7 and 28 days, while the complete replacement of distilled water with the treated leachate (i.e., 100\%) decreased compressive strength at the ages of 7 and 28 days by $17 \%$ and $25 \%$ relative to the control sample, respectively. The compressive strength of the samples is dependent on the physical and chemical properties of water. Increased biochemical oxygen demand (BOD) and chemical oxygen demand (COD) reduced compressive strength (Asadollahfardi et al. 2016). The treated leachate reduced the compressive strength of the samples. A rise in the leachate concentration changed compressive strength at a larger rate. A coefficient $f$ can be defined for the compressive strength of the treated leachate-fabricated samples as:

$$
f=\left(1-f_{c}^{\prime} / f_{c}\right) * 100
$$

where is the compressive strength of the treated leachate-fabricated sample at the age of 28 days, while is the compressive strength of the control sample at the age of 28 days. Also, the coefficient $v$ could be defined for the ultrasonic pulse velocity as: 
$v=\left(1-v^{\prime} / v_{c}\right) * 100$

where $v^{\prime}$ denotes the ultrasonic pulse velocity of the treated leachate-fabricated sample at the age of 28 days, while represents the ultrasonic pulse velocity of the control sample at the age of 28 days. As mentioned, increased treated leachate concentration in concrete would raise $f$ and $v$ (Fig.3). At the treated leachate content of $100 \%, f$ and $v$ increased by $24.5 \%$ and $6.5 \%$, respectively. The increase differences of the two coefficients can be explained by the fact that the ultrasonic pulse velocity has a wider range (i.e., 4510-4826) than compressive strength (38.46-50.98 MPa). However, the two coefficients have very similar variation trends, and the compressive strength of the concrete samples can be accurately estimated by the ultrasonic pulse velocity test. In other words, it is possible to predict compressive strength without performing compressive strength tests.

Fig.4 depicts the SEM results of the treated leachate-fabricated samples. SEM is used to examine the microstructure of concrete and could be a good measure to evaluate the physical and mechanical properties of concrete. Consistent with treated wastewater (Asadollahfardi et al. 2016; Saxena and Tembhurkar 2019), the treated leachate induced pores in concrete; pores increased as the leachate concentration increased. This is in line with the ultrasonic pulse velocity results, in the sense that a rise in the leachate content increased pores in the concrete, raising the pulse velocity and diminishing compressive strength. SEM images with a magnification of $10 \mathrm{~nm}$ were used to investigate cracks in the concrete. At low leachate concentrations, no cracks were observed, as with the distilled water-fabricated sample. However, a rise in the treated leachate concentration led to cracks (the red area in Fig.4). The complete replacement of distilled water with the treated leachate dramatically raised the number of cracks.

Table 4 compares the compositions of the samples at the age of 28 days. As can be seen, the treated leachate increased $\mathrm{MgO}, \mathrm{SO}_{3}$ and $\mathrm{CaO}$ relative to the control sample. 
Table 4 Percentage of parameters in 28-day concrete, containing treated leachate and distilled

water

\begin{tabular}{ccc}
\hline $\begin{array}{l}\text { Existed } \\
\text { compounds }\end{array}$ & $\begin{array}{l}\text { Samples } \\
\text { containing } \\
\text { treated leachate } \\
(\%)\end{array}$ & $\begin{array}{l}\text { Samples } \\
\text { containing } \\
\text { distilled water } \\
(\%)\end{array}$ \\
\hline $\mathbf{N a}_{\mathbf{2}} \mathbf{O}$ & 1.41 & 1.825 \\
$\mathrm{MgO}$ & 2.067 & 1.791 \\
$\mathbf{A l}_{\mathbf{2}} \mathbf{O}_{\mathbf{3}}$ & 3.998 & 6.189 \\
$\mathbf{S i O}_{2}$ & 21.213 & 31.514 \\
$\mathbf{P}_{\mathbf{2}} \mathbf{O}_{\mathbf{5}}$ & 0.105 & 0.11 \\
$\mathbf{S O}_{\mathbf{3}}$ & 1.524 & 1.202 \\
$\mathbf{K}_{\mathbf{2}} \mathbf{O}$ & 0.614 & 1.262 \\
$\mathrm{CaO}$ & 43.615 & 30.856 \\
$\mathbf{T i O}_{2}$ & 0.35 & 0.458 \\
$\mathrm{MnO}_{\mathbf{F}}$ & 0.0164 & 0.115 \\
$\mathbf{F e}_{\mathbf{2}} \mathbf{O}_{\mathbf{3}}$ & 3.43 & 3.589 \\
\hline
\end{tabular}

Heavy metal leakage was investigated at the age of 28 days and the highest leachate concentration (i.e., $100 \%$ leachate and $0 \%$ water) by the modified TCLP method according to ASTM-D3987. The results showed that the concentration of heavy metals did not exceed the allowable limits; the quantities of heavy metals were extremely lower than the limits. The leakage rates of $\mathrm{As}, \mathrm{Cd}, \mathrm{Ag}, \mathrm{Cr}, \mathrm{Pb}$, Se, and $\mathrm{Hg}$ were nearly $0 \%$, and the leakage rate of Ba was $0.532 \mathrm{mg} / \mathrm{l}$, which is significantly smaller than the permissible limit. Mostafa and Peters (2016) and Zhan and Peon (2015) reported that the leakage of all heavy metals was lower than the permissible limit.

\section{Conclusion}

Population growth and industrialization have led to an increase in waste per capita and leachate all around the world. The reduction of water per capita in the world motivated the development of a solution to compensate for the reduced water per capita in the construction industry. The present study utilized different concentrations of treated leachate as an alternative to water in concrete production. The treated leachate shortened the initial cement setting time; however, it can be said that the results are consistent with the ASTM-C191 and BSI 3148 Standards. The use of treated leachate increased the concrete slump. The concrete slump at $100 \%$ treated leachate concentration was $16 \%$ higher than that at $100 \%$ distilled water concentration. Organic materials decreased compressive strength (Ghrair et al. 2018); a rise in the treated leachate content reduced the compressive strength of the concrete. The complete replacement of 
distilled water with the treated leachate decreased compressive strength by $25 \%$ as compared to the control sample. The SEM results were found to be consistent with the ultrasonic pulse velocity test results. The SEM images depicting cracks showed reduced ultrasonic wave velocity, implying reduced compressive strength. An increase in the treated leachate content increased cracks and diminished the ultrasonic wave velocity. According to the ASTM-C94 and BS 3184 Standards, the mixing water that allows for $90 \%$ of the compressive strength of the control sample would be acceptable. The leachate concentration of up to $20 \%$ led to $90 \%$ of the compressive strength of the control sample. Treated leachate-fabricated concrete can be used in light-load applications, such as street curbs and floors. According to the BS6717 Standard, concrete floors are divided into four groups based on the bearing capacity, including medium traffic floorings with a compressive strength of $40 \mathrm{Mpa}$, a treated leachate concentration of up to $80 \%$, and higher than $80 \%$ leachate concentration for light-load applications with a compressive strength of $30 \mathrm{MPa}$. Leachate-fabricated concrete meets the requirements of sidewalk floorings even at $100 \%$ leachate concentration and could be a perfect alternative to water.

\section{Declarations}

\section{Ethics approval and consent to participate}

This research has not involved human participants and/or animals.

\section{Consent for Participate}

Not applicable.

\section{Consent for publication}

Not applicable

\section{Availability of data and materials}

Not applicable

\section{Competing interests}

The authors declare that they have no competing interests.

\section{Conflicts of interest}

The authors have no conflicts of interest to declare that are relevant to the content of this article.

\section{Funding}

No funding was received to assist with the preparation of this manuscript.

\section{Authors' contributions}


All authors contributed to the study conception and design. Material preparation, data collection and analysis were performed by Negar Esmaeili. The first draft of the manuscript was written by Negar Esmaeili and Nima Heidarzadeh and all authors commented on previous versions of the manuscript. All authors read and approved the final manuscript.

\section{Acknowledgements}

The authors express their thanks to Environmental Engineering Group of Kharazmi University and University of Tehran for providing the necessary help and research facility to conduct the current study.

\section{References}

Al-Jabri KS, Al-Saidy AH, Taha R, Al-Kemyani AJ (2011) Effect of using wastewater on the properties of high strength concrete. In: Procedia Engineering. pp 370-376

Asadollahfardi G, Delnavaz M, Rashnoiee V, Ghonabadi N (2016) Use of treated domestic wastewater before chlorination to produce and cure concrete. Constr Build Mater.

https://doi.org/10.1016/j.conbuildmat.2015.12.039

ASTM C136 (2004) Standard Method for Sieve Analysis of Fine and Coarse Aggregates, American Society for Testing and Materials, Philadelphia.

ASTM C1723-10 (2010) Standard Guide for Examination of Hardened Concrete Using Scanning Electron Microscopy (SEM), West Conshohhocken, PA.

ASTM C191 (2004) Standard Test Method for Setting of Hydraulic Cement by Vicat Needle, American Society for Testing and Materials, Philadelphia.

ASTM C192 (2004) Standard Practice for Making and Curing Concrete Test Specimens in the Laboratory, American Society for Testing and Materials, Philadelphia.

ASTM C33 (2004) Standard Specification for Concrete Aggregates, American Society for Testing and Materials, Philadelphia.

ASTM C597 (2004) Standard Test Method for Pulse Velocity Through Concrete1, American Society for Testing and Materials, Philadelphia.

ASTM D3987-06 (1995) Standard Guide for shake extraction of solid waste with water, West Conshohhocken, PA.

ASTM E1621 - 13 Standard Guide for Elemental Analysis by Wavelength Dispersive X-Ray Fluorescence Spectrometry. 
ASTM-C143 (2004) Standard Test Method for Slump of Hydraulic-Cement Concrete, American Society for Testing and Materials, Philadelphia.

ASTM-C150 (2004) Standard Specifications for Portland Cements, American Society for Testing and Materials, Philadelphia.

BSI 8500-1 (2006) Concrete. Complementary British Standard to BS EN 206-1. Method of specifying and guidance for the specifier. BSI, London, UK.

BSI 1881-108 (1983) Testing Concrete Method for Making Test Cubes from Fresh Concrete.

Cebeci OZ, Saatci AM (1989) Domestic sewage as mixing water in concrete. ACI Mater J. https://doi.org/10.14359/9743

Chang EE, Chiang PC, Lu PH, Ko YW (2001) Comparisons of metal leachability for various wastes by extraction and leaching methods. Chemosphere. https://doi.org/10.1016/S0045-6535(01)00002-9

Cusidó JA, Cremades L V. (2012) Environmental effects of using clay bricks produced with sewage sludge: Leachability and toxicity studies. Waste Manag. https://doi.org/10.1016/j.wasman.2011.12.024

Dungan RS, Dees NH (2009) The characterization of total and leachable metals in foundry molding sands. J Environ Manage. https://doi.org/10.1016/j.jenvman.2007.12.004

El-Nawawy OA, Ahmad S (1991) Use of treated effluent in concrete mixing in an arid climate. Cem Concr Compos. https://doi.org/10.1016/0958-9465(91)90009-7

Ghrair AM, Al-Mashaqbeh OA, Sarireh MK, et al (2018) Influence of grey water on physical and mechanical properties of mortar and concrete mixes. Ain Shams Eng J.

https://doi.org/10.1016/j.asej.2016.11.005

Ismail ZZ, Al-Hashmi EA (2011) Assessing the recycling potential of industrial wastewater to replace fresh water in concrete mixes: Application of polyvinyl acetate resin wastewater. J Clean Prod. https://doi.org/10.1016/j.jclepro.2010.09.011

Karamalidis AK, Voudrias EA (2007) Cement-based stabilization/solidification of oil refinery sludge: Leaching behavior of alkanes and PAHs. J Hazard Mater. https://doi.org/10.1016/j.jhazmat.2007.02.032

Luhar S, Chaudhary S, Luhar I (2019) Development of rubberized geopolymer concrete: Strength and durability studies. Constr Build Mater. https://doi.org/10.1016/j.conbuildmat.2019.01.185

Ma G, Garbers-Craig AM (2009) Stabilisation of $\mathrm{Cr}(\mathrm{VI})$ in stainless steel plant dust through sintering using silica-rich clay. J Hazard Mater. https://doi.org/10.1016/j.jhazmat.2009.03.098

Mahasneh BZ (2014) Assessment of replacing wastewater and treated water with tap water in making concrete mix. Electron J Geotech Eng 
Manjunatha M and, Dhanraj MR (2017) An Experimental Study on Reuse of Treated Waste Water in Concrete - A Sustainable Approach. Int J Latest Eng Res Appl ISSN 2455-7137

Meena K, Luhar S (2019) Effect of wastewater on properties of concrete. J Build Eng. https://doi.org/10.1016/j.jobe.2018.10.003

Mokhtarani N, Khodabakhshi S, Ayati B (2014) UV-TiO2 Photocatalytic Degradation of Compost Leachate. IQBQ. 14 (20), 137-146 (in Farsi).

Mostafa MK, Peters RW (2017) Reuse paint wastewater in the manufacture of cement bricks and tiles. J Mater Cycles Waste Manag. https://doi.org/10.1007/s10163-016-0485-0

NIKHIL.T.R NT., SUSHMA. R SR, et al (2011) Impact of Water Quality on Strength Properties of Concrete. Indian J Appl Res. https://doi.org/10.15373/2249555x/july2014/60

Noruzman AH, Muhammad B, Ismail M, Abdul-Majid Z (2012) Characteristics of treated effluents and their potential applications for producing concrete. J Environ Manage.

https://doi.org/10.1016/j.jenvman.2012.05.019

Ooi SL, Salim MR, Ismail M, Ali MI (2001) Treated Effluent in Concrete Technology. J Teknol. https://doi.org/10.11113/jt.v34.648

Pal Kaur N, Kumar Shah J, Majhi S, Mukherjee A (2019) Healing and simultaneous ultrasonic monitoring of cracks in concrete. Mater Today Commun. https://doi.org/10.1016/j.mtcomm.2018.10.022

Reddy Babu G, Venkata Ramana N (2018) Feasibility of wastewater as mixing water in cement. In: Materials Today: Proceedings

Renou S, Givaudan JG, Poulain S, et al (2008) Landfill leachate treatment: Review and opportunity. J. Hazard. Mater.

Saricimen H, Shameem M, Barry M, Ibrahim M (2014) Testing of Treated Effluent for Use in Mixing and Curing of Concrete. J Pet Miner Res insititute

Saxena S, Tembhurkar AR (2019) Developing biotechnological technique for reuse of wastewater and steel slag in bio-concrete. J Clean Prod. https://doi.org/10.1016/j.jclepro.2019.04.363

Shekarchi M, Yazdian M, Mehrdadi N (2012) Use of biologically treated domestic waste water in concrete. Kuwait J Sci Eng

Silva M, Naik TR (2010) Sustainable use of resources - Recycling of sewage treatment plant water in concrete. In: 2nd International Conference on Sustainable Construction Materials and Technologies

Sruthi T, Gandhimathi R, Ramesh ST, Nidheesh P V. (2018) Stabilized landfill leachate treatment using heterogeneous Fenton and electro-Fenton processes. Chemosphere. 
Su N, Miao B, Liu FS (2002) Effect of wash water and underground water on properties of concrete. Cem Concr Res. https://doi.org/10.1016/S0008-8846(01)00762-1

Terro M, Al-Ghusain I (2003) Mechanical properties of concrete made with treated wastewater at ambient and elevated temperatures. Kuwait J Sci Eng

Xu Q, Siracusa G, Di Gregorio S, Yuan Q (2018) COD removal from biologically stabilized landfill leachate using Advanced Oxidation Processes (AOPs). Process Saf Environ Prot.

https://doi.org/10.1016/j.psep.2018.09.014

Zhan BJ, Poon CS (2015) Study on feasibility of reutilizing textile effluent sludge for producing concrete blocks. J Clean Prod. https://doi.org/10.1016/j.jclepro.2015.03.083

\section{Figures}

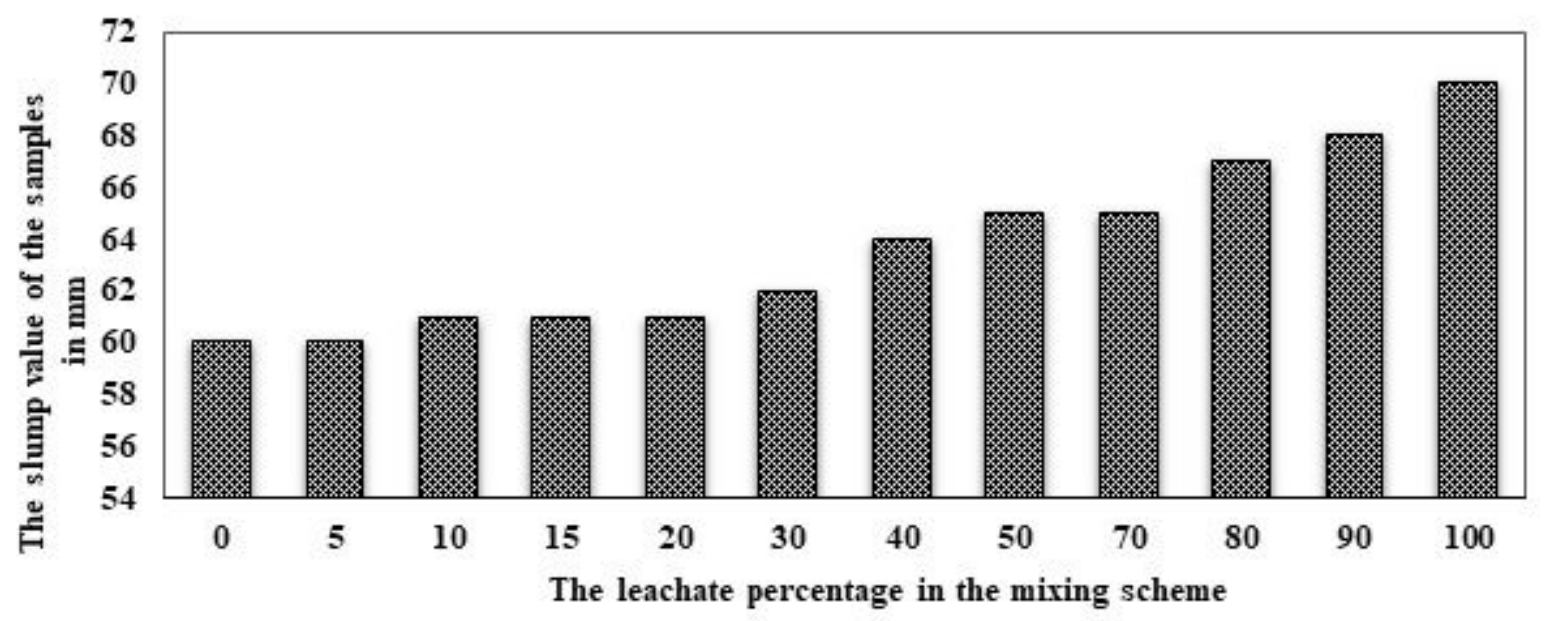

Figure 1

Results of the slump test for samples made with different percentages of treated leachate 


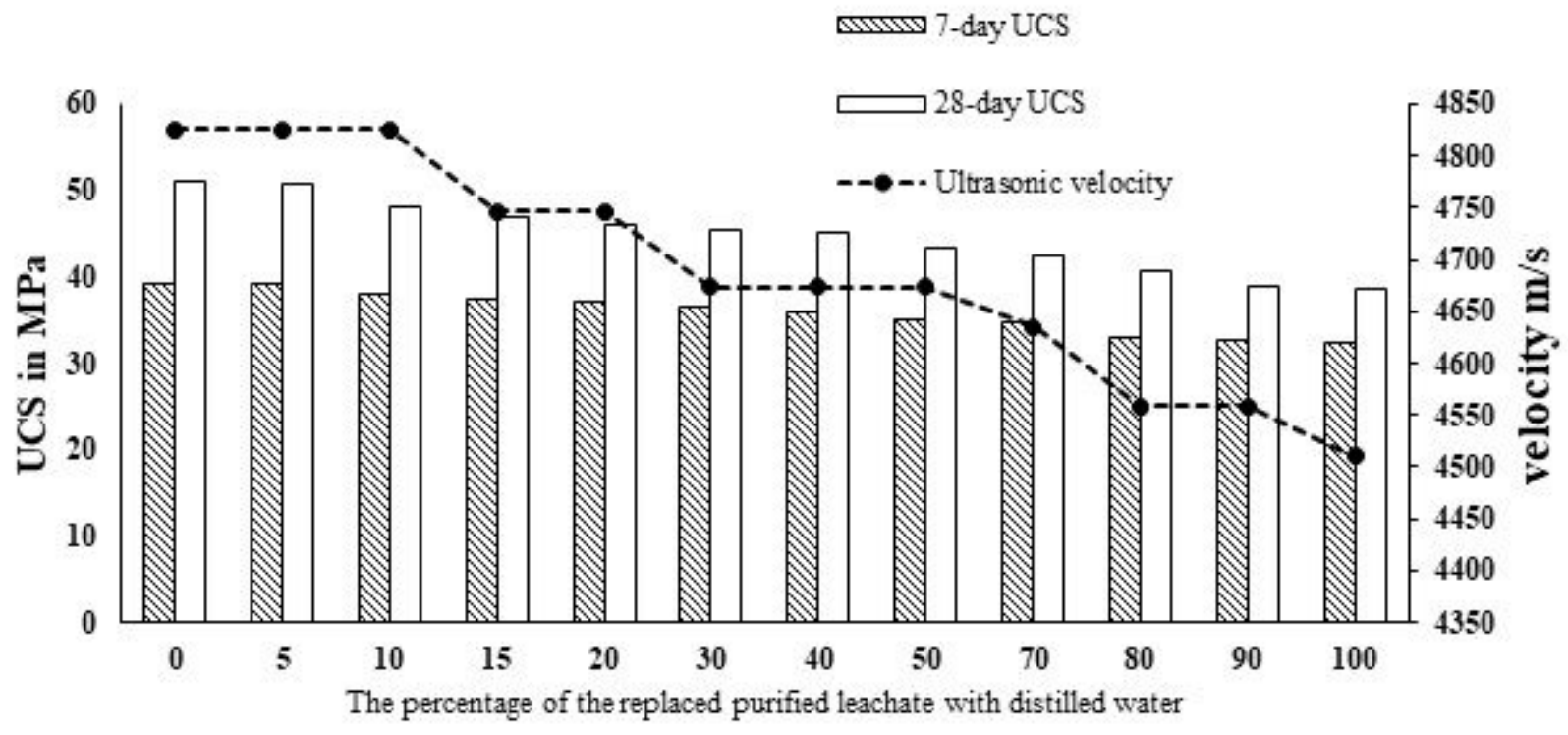

Figure 2

Results of the ultrasonic test and USC test of the samples made with different percentages of treated leachate

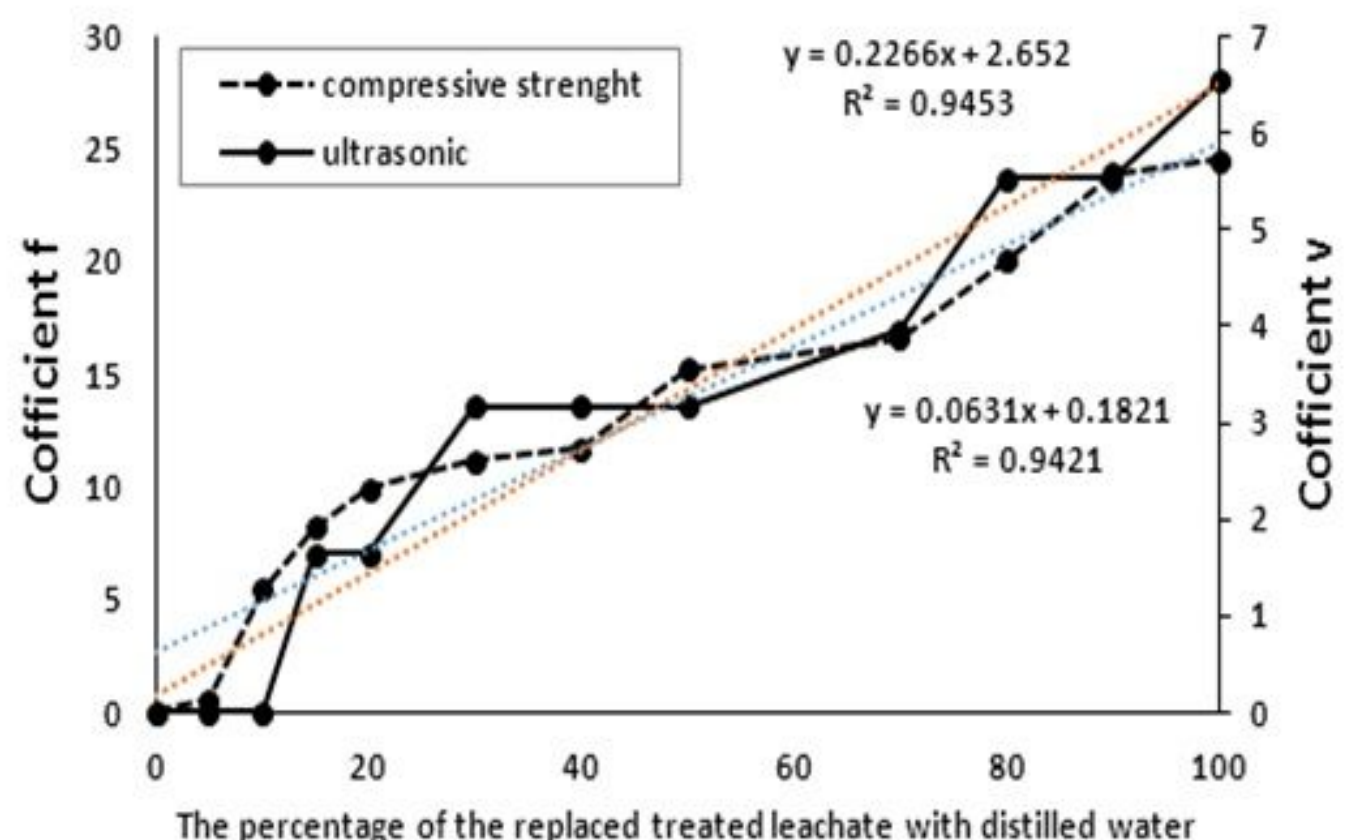

Figure 3

The increasing process of the coefficient $f$ by increasing the leachate percentage 


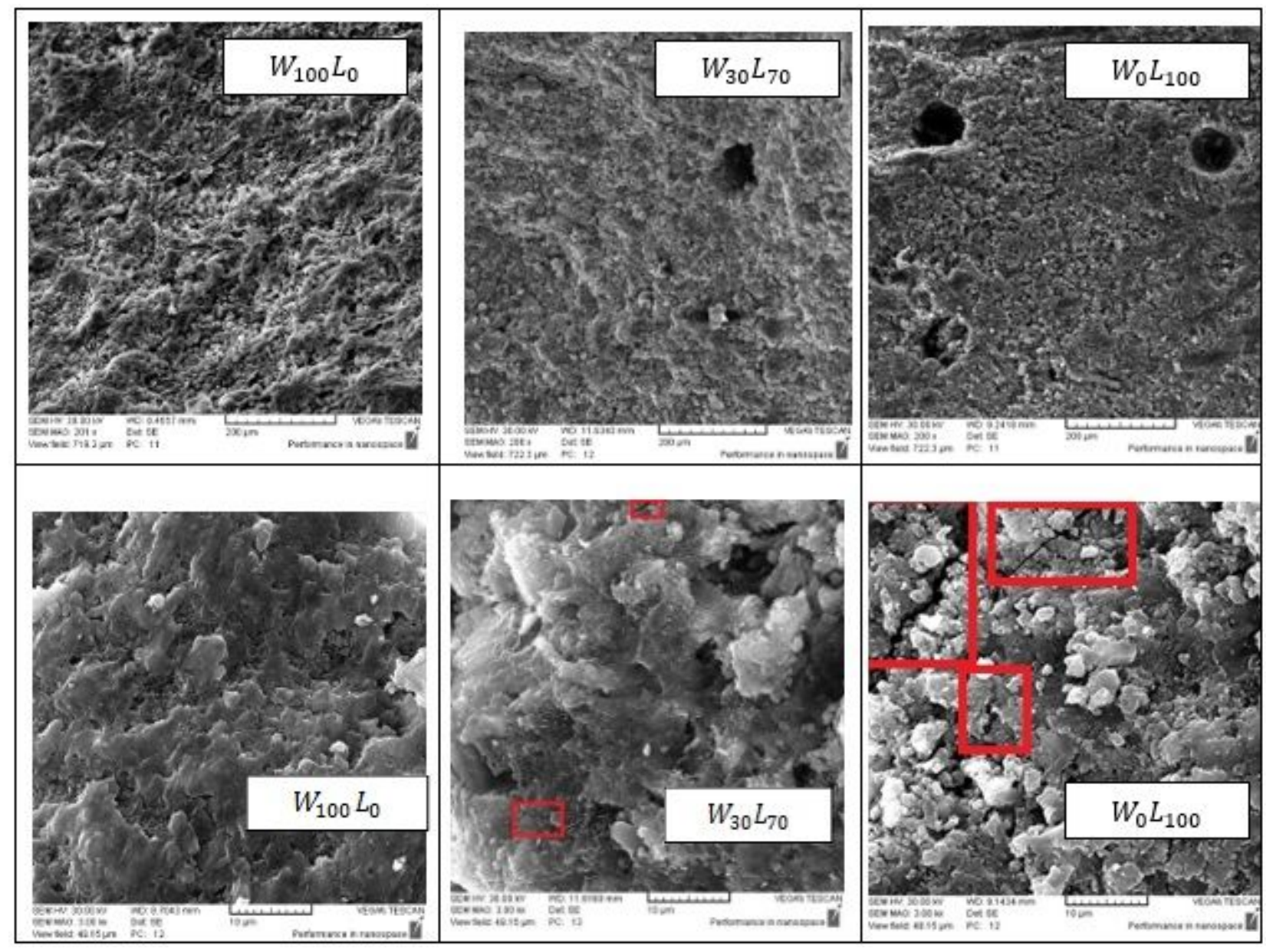

Figure 4

Increasing process of porosity and crack in concrete by increasing the percentage of treated leachate at 200 and $10 \mu \mathrm{m}$ magnification 